Article

\title{
Prevention and Suppression of Environmental Crimes in the Light of the Actions of Non-Governmental Organizations in the Iranian Legal System
}

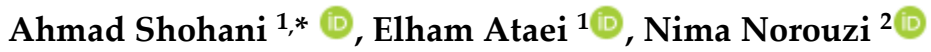 \\ ${ }^{1}$ School of political science and international relationships, Payam Noor University, Tehran, Iran \\ 2 School of Law, Department of Human Sciences, Islamic Azad University, Tehran, Iran \\ *Correspondence: Ashohani1300@gmail.com
}

How to cite this paper: Shohani, A., Ataei, E., \& Norouzi, N. (2021). Prevention and Suppression of Environmental Crimes in the Light of the Actions of Non-Governmental Organizations in the Iranian Legal System. Research Journal of Ecology and Environmental Sciences, 1(1), 57-70.

Retrieved from

https://www.scipublications.com/journal/index.php/rjees/article/view/97

Received: July 20, 2021 Accepted: August 24, 2021 Published: August 25, 2021

Copyright: (C) 2021 by the authors. Submitted for possible open access publication under the Creative Commons Attribution (CC BY) license

(http://creativecommons.org/licenses /by/4.0/).

\begin{abstract}
Today, non-governmental actors play an important role in the national and international arena. The geographical diversity of their field of activity and their different functions have made it impossible for government actors to be indifferent to the role of these new actors. NGOs act as "rival" or "partner" governments. In human rights, these organizations are more of a rival to governments; While on health, development, and the environment, they are considered more as partners of governments. In the Iranian legal system, the active role of these organizations in terms of environmental protection is undeniable; But there are still many gaps in the reaction phase; Appropriate conditions must be provided for the active participation of these actors in environmental litigation; In such a way that they can achieve their desired position in criminal proceedings as quasi-prosecutors.
\end{abstract}

Keywords: NGOs; Crime Prevention; Environment; Litigation; Participation.

\section{Introduction}

Unbridled industrial development has transformed nature and caused irreparable damage to the human environment. Therefore, taking measures at the national and international levels as one of the important measures is on the agenda of many countries; Many conferences have been held in this regard so far. One of the major and decisive mechanisms to achieve this important goal is identifying and involving NGOs in environmental issues. The prevention principle is one of the most well-known principles of international environmental law and is considered the "golden rule" in this field. This principle is explicitly enshrined in the Rio 1992 Declaration on Environment and Development; Achieving this principle in line with the implementation of Chapter 27 of Agenda 21 requires the role of non-governmental organizations. This agenda focuses on the role of social actors; In general, these actors are classified into two types of individuals, associations, and groups. Women, youth, indigenous peoples, farmers, scientists are among the real people who have been considered in environmental protection; While local councils, trade unions, and NGOs are among the group actors; There are roles for them. Reflection on these actors reveals several facts; First, these actors are divided into two large groups of individuals and legal entities; second, they share a non-governmental nature; and finally, they share a direct or indirect goal in environmental protection[1].

Today, non-governmental organizations contribute to the criminal justice system in achieving its goals in two ways. On the one hand, by performing their duties in reporting and reporting crimes, they help the criminal justice system detect and prosecute crimes, and on the other hand, they help specific victims by playing a role in the criminal process. Sensitizing public opinion and timely advertising and information can play an important role in protecting the environment[2,3]. 
Achieving high environmental goals is difficult regardless of the role of NGOs in the various stages of the formation of environmental norms and their monitoring and implementation. The social nature of the crime phenomenon requires that all social capacities be used as much as possible to prevent and suppress crime. The participation of nongovernmental organizations in the criminal process is considered one of these capacities; Something that can be effective in the success of prevention programs in the community. Therefore, a participatory approach and preventive measures can prevent many environmental crimes[3-10].

In addition to prevention, it is very important to take a reactive approach to criminalize acts of environmental degradation and pollution; By identifying and expanding the competence of those in charge, from public and governmental to private and non-governmental, the protection of privacy will become a better and easier process. Therefore, the interaction of non-governmental organizations with the government and the competence of these organizations in environmental criminal cases has an important role in protecting the environment in the control and enforcement phase[11-17].

The question is whether Iranian law has a role for NGOs in preventing environmental crimes. If so, what is this role in Iranian law, and if not, what action should be taken in the field of legislation? The answers to these questions reveal the type of attitude of the Iranian legislature towards the environment in environmental policies and explain the criteria and mechanisms adopted in the form of participatory prevention for environmental protection and sustainable use of the country's natural resources[18-24].

Depending on the interpretation of the word prevention, its mechanisms also vary. In providing a broad interpretation of prevention in environmental crimes, the purpose is various criminal and non-criminal measures and mechanisms. In the case of providing a narrow interpretation of this concept, only criminal mechanisms are considered. In other words, prevention in its broadest sense includes a wide range of actions and mechanisms; While in its narrow and specific sense, it includes only non-criminal acts[25, 26].

Accordingly, if we refer to the specific meaning of prevention, we have only action measures in front of us, and if we refer to its general and broad meaning, in addition to active measures, we have also considered reactionary measures. With this interpretation, in this article, each of the non-criminal and criminal measures and mechanisms in the field of environment is examined in the light of the actions of non-governmental organizations.

\section{NGO's in the light of a preventive approach to environmental crime}

So far, several definitions of NGOs have been provided nationally and internationally, but the diversity of these organizations is such that it is difficult to provide a single definition of them; However, these organizations have something in common in terms of their private and non-commercial nature. The definition of environmental NGOs reads as follows[27-33]:

"Environmental non-governmental organizations refer to non-governmental, nonprofit and non-political organizations that are organized from the gathering of natural persons voluntarily and in such a way that these persons by drafting a statute, from the date of registration in the official authorities of the country as a Legal entity to achieve common goals and ideals in the field of protection and protection of the environment to work in the cities and villages of the country and if possible at the international level" [8].

These organizations in Iran are proof that these organizations have existed in practice for a long time in the form of charitable organizations, whether religious or welfare, such as boards and groups of breastfeeding and chain and managing the reservoirs in Iran. In other words, these institutions, except for registration, had all the components of an NGO. In Iranian law, perhaps the Commercial Code and the Regulations for Registration of Non-Commercial Organizations and Institutions approved in 1958 can be considered the first regulations defined by non-governmental organizations. 
Some countries, such as France and Switzerland, have pioneered in this area; For more than a century, the status of these organizations has been regulated by the legislature. France, for example, sought to regulate the formation of these organizations bypassing the Association Law on 1 July 1901. Article 1 of this law states: "Association is a contract according to which two or more persons permanently share their knowledge and activities to achieve a goal other than profit" (Loi relative au contrat d'association). This article has some structural elements of non-governmental organizations such as private nature, non-profit nature and continuity, and continuity of activities. Has been postponed to registration, while in Swiss civil law, associations have legal personality as soon as they are formed and do not need to be registered [34].

Therefore, this law is considered the cornerstone of the formation and establishment of non-governmental organizations in the French legal system and has provided a suitable platform for the participation of these organizations. In France, many NGOs are active in various fields, including the environment; This indicates the importance of the environment and an appropriate and legally defined context for forming and establishing these organizations. In addition to Law 1901, other laws, such as the French Environmental Act of 2005, directly address the role of environmental associations and prescribe their participation in the actions of public institutions and bodies related to the environment and administrative and judicial authorities $[35,36]$.

The Constitution of the Islamic Republic of Iran envisages two important principles in the field of environmental protection as well as the legitimacy of the establishment and activity of non-governmental organizations. In principle 50 of this law, environmental protection is considered a public duty. In addition, activities that cause pollution or destruction of the environment are prohibited. According to this principle, all Iranians are obliged to protect and protect their environment; Accordingly, the establishment and participation in environmental non-governmental organizations and membership in them can be considered in line with Article 50 of the Constitution and the second principle according to which the creation and activity of non-governmental organizations are inferred is Article 26 of the Constitution[37]. Adopting the principle of freedom of association as enshrined in Article 20 of the Universal Declaration of Human Rights, the legislation stipulates that "Parties, associations, political and trade unions and Islamic associations or recognized religious minorities are free, provided that the principles of independence Do not violate freedom, national unity, Islamic norms and the basis of the Islamic Republic. "No one can be barred from participating in them or forced to participate in any of them." In principle, the goals and ideals outlined in the constitutions are quite general; It is on this basis that they refrain from going into details and refer its examination to ordinary laws. In this regard, the principle deals with two issues related to the formation of nongovernmental organizations: the principle of freedom of association and the principle of free participation of individuals in these communities. The legislator has used terms such as populations and associations to include popular gatherings (non-governmental organizations); In the last part of this principle, the issue of the right of individuals to participate or not to participate in any of these gatherings is explicitly raised. A noteworthy point in this principle is the same two features of non-opposition to the general principles of the constitution and the non-obligation to participate in them, which is also mentioned in paragraph A of Article 1 of the Executive Regulations on the Establishment and Activities of Non-Governmental Organizations approved in 2005. Given the above, the role of nongovernmental organizations in the participatory prevention of environmental crimes is examined[38].

\subsection{Participation concerning environmental crimes prevention}

In general, the relationship between government and non-governmental organizations can be considered from different aspects. This relationship varies according to the 
study area and is very diverse. In general, the presence and participation of non-governmental organizations in the two processes of formation of international norms and their monitoring and implementation is realized. This diversity gives rise to different roles for these organizations; As in a field as a complement to government and international organizations; While in another area, it manifests itself as a rival to the government. Therefore, the participation of these organizations is not equal in all levels and fields; In some areas, such as humanitarian law, environmental law, and development, they have an effective and prominent presence; While in some areas, such as human rights, these organizations stand up to governments and are seen as their fiercest rivals[39].

As mentioned above, the fifty-sixth principles of the Constitution of the Islamic Republic of Iran are defined as two basic principles on the importance of the environment and its protection and the freedom of association. The combination of these principles, on the one hand, and the existence of other legislative and sub-legislative provisions related to environmental protection and the establishment and establishment of non-governmental organizations, on the other hand, raises some fundamental questions about participatory prevention[40].

The diversity of non-governmental organizations and their different goals give rise to different functions for these organizations. Given the diverse functions of these organizations, the important question is whether environmental crime prevention is on their agenda? Answering this question requires the following points: First, a reflection on the prevailing regulations indicates that in the Iranian legal system, only a handful of different materials are allocated to the participation of non-governmental organizations; There is no comprehensive and independent law on participatory prevention; Because crime prevention programs are generally formed in a completely formal and governmental context and do not consider a suitable position for non-governmental organizations [9[second, that the issue of environmental crime prevention Less attention has been paid.

More than two decades after the adoption of the constitution, the Iranian judiciary has recently, through the proposal of the "Crime Prevention Bill," considered the implementation of part of its duties in the field of prevention, which is the subject of the fifth paragraph of Article One Hundred and Fifty-six of the Constitution. . Article 1 of the bill defines crime prevention as "predicting, identifying and evaluating the occurrence of crime and taking the necessary measures and measures to prevent its occurrence." This article has prescribed three types of social, judicial, and disciplinary crime prevention and has established general and specific elements for them[41-47].

Social prevention is very important; This type of prevention allows the presence of non-governmental organizations. According to the bill, social prevention is "educational, cultural, economic and social measures and methods of the government, non-governmental organizations and non-governmental organizations in the field of improving the social environment and the physical environment to eliminate or reduce the social factors of crime." To implement the goals of this bill and to achieve social prevention, Article 7 of the bill envisages a pillar called "Social Commission for the Prevention of Crime." Paragraph " $\mathrm{f}$ " of this article makes one of the duties of the commission "assisting in the establishment and strengthening of non-governmental organizations, associations, and nongovernmental organizations in the field of crime prevention." Facilitating the establishment of these institutions plays a unique role in preventing environmental crimes and protecting the environment[48-54].

Despite the judiciary taking a big step towards implementing the constitutional duty of prevention, the crime prevention bill seems to be disregarding environmental crimes. However, the bill does not seem to have the capacity to cover such crimes, despite its implicit nature. In particular, there is a strong belief that access to a healthy environment is a prerequisite for realizing other fundamental rights protected by criminal law and intergenerational environmental justice. Today, crime prevention programs in the official 
and governmental form alone are not very popular; The success of these programs depends on the participation of all civil society actors. In this regard, important international environmental instruments, such as the Rio Declaration and Order 21, contain elements that emphasize the participation of all non-governmental actors in the protection of the environment. Chapter 23 of Order 21 is dedicated to strengthening the role of major groups and emphasizes the serious commitment and participation of all social groups in achieving their goals, policies, and mechanisms.

Chapter 27 of the order is dedicated to strengthening non-governmental organizations; This document introduces partners for sustainable development. The chapter begins with the phrase: "NGOs play a vital role in the process of democracy." These organizations are very diverse in activity (local, regional, national and global) and the subject of activity (human rights, humanitarian law, development, environment, etc.). To further explain, the issue of participatory prevention is examined in the light of the activities of non-governmental organizations[55].

\subsection{Participation Participatory in the field of environment}

Non-governmental organizations move within the framework of the goals set out in their statutes and make decisions on various issues following the established purpose and subject matter. Compared to government organizations and institutions, these organizations generally face many financial and technical limitations. Therefore, these organizations use tools and methods to achieve their goals more or less used by other organizations. Non-governmental is also used. Applying this according to paragraph 5 of Article 3 of the recent law is one of the cases included in the law of counting, and to properly implement the provisions of the law, supervision of all matters mentioned in Article 3 and inspection in these areas is entrusted to the legal unit "Food from radiation contamination, including the protection of people and future generations in general, is the oversight role of the Atomic Energy Organization." Applying the prevention principle and using noncriminal applications is considered the first and easiest way to protect natural elements. Experience and scientific expertise prove that prevention should be the "golden rule" of the environment for ecological and economic reasons[56].

In some cases, it is impossible to compensate for the damage to the environment: the extinction of animal or plant species, the erosion and discharge of persistent pollutants into the sea, create uncontrollable and irreversible conditions. Even when the damage is compensable, the costs of environmental remediation are very high. In many cases, it is impossible to prevent all possible risks of such injuries. In such cases, to protect the environment and the rights of others, measures may be taken to allow risky activities to be minimized [57].

The material realm of the environment is vast and can be violated in various forms. The close relationship between the elements of the environment is a matter of great importance; Because this relationship distinguishes environmental crimes from other crimes; In fact, it brings crimes in this area to a new level that should be given special attention. Overall, the breadth of the environmental issue leads to a variety of crimes committed against it. Therefore, the diversity of criminals is the logical result of the diversity of crimes; In practice, determining the level of involvement of each perpetrator of environmental crimes will not be easy. According to the above explanations, the perpetrators of environmental crimes can be divided into natural and legal persons. However, the exact determination of the perpetrator or perpetrators of these crimes and the degree of participation of each of these persons in these crimes is not the same[58]. For example, in air pollution, determining the exact amount of gases emitted by each of the air pollutants (industrial plants and car owners) on the one hand and the contribution of each manufacturer (non-standard car manufacturers and producers of unsuitable and non-standard fuel) in causing pollution from, On the other hand, it isn't easy. At the same time, trans- 
boundary pollution must be added to it; This is due to the close relationship between environmental elements and the impact and impact of each of them on each other, and as a result, it is difficult to identify the polluters and the source of pollution.

Identifying the culprit against environmental crimes faces several major problems; If the environment is considered as insane, this insane has no real or legal personality; The value of the environment is also inherent; Its value, in essence, should not be weighed against the benefit it owes to humankind; First of all, respect for it should depend on its intrinsic value, not the importance it brings to human beings.

Given the perceived characteristics of environmental crimes, is the prevention of these crimes different from other crimes? It is certain that the prevention of environmental crimes is very important and requires an integrated and comprehensive program; NGOs will play a pivotal role in this[59].

Functionally, the nature of the actions of non-governmental organizations is more in favor of non-criminal prevention; the tools and methods used by these organizations are not police and repressive. These methods are usually non-violent; In this respect, they can not be compared with government institutions' coercive and reactionary mechanisms. For example, these organizations prevent environmental degradation by publishing various scientific articles on environmental problems in their publications or publishing statistics in their reports.

Therefore, environmental NGOs try to take the following preventive measures by informing, educating, and mobilizing public opinion and announcing a threat to the state of the environment[60]

2.2.1. information on the state of local, regional, national, and international environmental status

Information is one of the common methods used by these organizations. In general, public access to and participation in information is not limited to environmental regulation but is a pre-eminent right of the government and its citizens in all democracies. Here the issue of information and information and citizen participation is very important; Because with their participation in decision-making, a suitable platform for democracy is provided. On the other hand, the observance of this right for citizens shows the government's attention to pluralism and the people's efforts in managing the country's affairs and their right to self-determination. Citizens' access to information and their participation in environmental issues is very important; Because access to environmental data and their participation in the decision-making process will directly affect citizens[12].

Conceptually, the right to access environmental information is conceived in two ways: First, the narrow meaning of this right is the freedom to seek information. According to this interpretation, the competent authorities provide the requested information to them at the request of natural or legal persons. This type of information has a passive aspect; Because competent public authorities provide information according to the request submitted by natural or legal persons; In other words, these authorities do not provide any information to individuals in the first place unless there is a prior request. For example, an environmental NGO may request information from the relevant authorities regarding implementing a development project, such as a dam or a highway. In this case, the public authorities are obliged to inform and respond to the relevant organization; Unless the requested information is one of the exceptions to the right to information, the information is refused[13].

Second, the right of access to environmental information in the broadest sense of the word, which is, in fact, the right of access to information or the right to receive information. Here we are talking about active information; Which means that the competent administrative authorities provide information on their initiative and do not need to request natural or legal persons. In other words, every citizen has the right to receive information about their environment, without the need for a prior request; Such as informing citizens about air pollution in metropolitan areas. 
It should be noted that some non-governmental organizations active in the field of the environment have accurate specialized information; This information can help decision-makers and implementers of large industrial projects in terms of environmental issues. For example, these organizations can collect data and analyze it, thus being effective as experts in the decision-making process. A clear example of this participation can be seen in specialized matters such as the study of the environmental effects of large-scale development projects; Thanks to the methods and tools and the expert role of these organizations, public rights in the environment can be defended[14].

\subsubsection{Public opinion polls}

One of the powerful tools of these organizations at the national and international levels is their external demonstrations, which turn them into a powerful pressure group. The actions of these organizations are very diverse; It ranges from the harsh protest of an environmental NGO against a country's nuclear tests at sea to the formation of a coalition to fight anti-personnel mines and the establishment of an international criminal court. Therefore, with the help of the formal and informal status that has been considered for them in the international arena, these organizations can be influential in international relations. It should be noted that in terms of effectiveness and credibility, the actions of these organizations are not the same; Because they are very diverse both in terms of the type of activity and geographical distance[62]. At the national level, these organizations, to achieve their goals to protect the environment, take measures such as preparing a petition to support an environmental issue, such as the relocation of the road connecting the north of the country to Khorasan province or opposing unauthorized destruction of natural resources. have given. Sometimes the actions of these organizations are such that they can be considered in the formation of minimum criteria, for example, companies producing products and food products or even health and pharmaceuticals and clothing and services to maintain their credibility in the market and Also, their convenience from the buyer point to the logo of the licensing of these institutions as a proof of the high quality of their products on their goods. Despite the many efforts of non-governmental organizations in Iran, these organizations have not yet been able to find their true place properly and act in an integrated manner in mobilizing public opinion to protect the environment and prevent environmental crimes[15, 16].

\subsubsection{Education}

Education plays an important role in preventing environmental degradation and pollution; Therefore, non-governmental organizations, by forming environmental networks, have started training to acquaint people with nature and how to interact with it. The establishment of specialized workshops to educate various people, including women, students, and children, has been in this direction. The main purpose of these pieces of training is to become more familiar with the environment and exchange information and experiences. Researching various environmental issues to collect accurate information and statistics on the state of the environment in different areas and research on animal and plant species are among the things that have been done within the framework of the actions of these organizations[17, 63-70].

\section{Right to sue NGOs in environmental litigation}

Explaining the role of non-governmental organizations in preventing environmental crimes requires that the position of the Iranian legal system in recognizing the right to sue for these organizations be examined and pathologically examined. Recognition of this right is one of the criteria for assessing the status and importance of the principle of participation; This plays an important role in implementing environmental regulations. In this regard, the existing laws and then some new orientations are examined[9]. 


\subsection{Comparative study}

Stakeholder stakeholders in environmental criminal cases are one of the most controversial theoretical and practical issues; Because environmental crimes are inherently special and cannot be compared to other crimes. In fact, in such crimes, the victim is the victim of silence who cannot protest and defend himself. In this situation, two assumptions are conceivable.

The first assumption is when other natural or legal persons are harmed by a crime against the environment; In this case, the legal system can also protect the environment due to the damaged private complaint.

The second assumption is when the crime is committed solely against the environment, without directly harming other people. Pollution of open rivers, seas, overfishing, poaching, and deforestation are some of the issues that result in the environment being a victim of environmental crimes; Something that does not seem to cause direct harm to individuals[11].

Regarding the latter premise, the crime should be considered an example of crime against the public interest, in which only the prosecutor or the public prosecutor has the necessary legal position to declare a crime and file a criminal lawsuit in a competent court. However, in many countries, including Iran, crimes against the environment are of secondary importance compared to other public crimes; prosecutors do not pay much attention to cases suspected of committing environmental crimes. So the question remains, what should be done about such crimes, and what can be done?

Undoubtedly, strengthening the role of non-governmental organizations in environmental litigation will be one of the important solutions to this problem. The success of these organizations and the recognition of the right to sue is not limited to domestic law but is also considered in some international instruments, such as the Convention on the Protection of the Environment through Criminal Law. Article 11 of the Convention designates environmental groups, including non-governmental organizations, as beneficiaries of environmental claims. In this regard, the 21st agenda calls on governments and legislators to establish judicial and administrative procedures to ensure legal redress and to compensate for environmental actions that are illegal or violate legal rights.

A comparative study of other countries' laws reveals that countries have tried to solve this problem by involving non-governmental organizations in the criminal process to answer this problem. For example, Articles 2-1 to 2-21 of the French Code of Criminal Procedure set out detailed provisions for the protection of victims' aid associations; According to these articles, if there are some conditions, these associations can play the role of plaintiff and even file a lawsuit. These associations can greatly help prosecutors and victims to achieve the goals of the criminal justice system.

In this legal system, in addition to the Code of Criminal Procedure, in other laws such as the Law on Consumer Protection and Environmental Law, environmental associations have been granted legal positions so that they can appear before administrative and judicial authorities under the conditions outlined in these laws. Thus, associations can exercise the rights conferred on the private plaintiff regarding acts that harm the public interest subject to the protection of these associations [12].

Lawmaking is one of the most important and main steps in environmental protection. Legislation alone is not enough to protect natural resources; Because the regulations must be implemented by the executive bodies. Achievement and goals outlined in the laws and regulations will be tangible if there is an executive guarantee for their non-implementation and the competent judicial authorities guarantee this performance guarantee. Accordingly, the legal system in the field of environment can be hoped for if each of the three powers performs its duties well.

In France, "the Administrative Court ruled that an association for the promotion of tourism and nature conservation may, following the objectives outlined in its articles of 
association, object to the issuance of a permit for the construction of a recycling plant following its objectives." Showed that trade unions, especially those related to the chemical industry interested in retaining the license, will have the right to sue. Contract. However, due to the inability of the association to prove the occurrence of material damages, it could not obtain a ruling on compensation "[13, 14].

Therefore, in most countries, efforts are made to provide a suitable basis for implementing environmental regulations based on the principles of prevention by administrative law, counteraction by criminal law, and compensation by civil law. The realization of this importance depends on the role of these organizations and their participation in the prevention and combating of environmental crimes. As mentioned, the establishment and participation of these organizations in French law has long been considered and has been able to play a significant role in the implementation of environmental regulations in this country.

\subsection{Iranian legal system}

In Iranian law, no law explicitly recognizes the right of non-governmental organizations to access the judiciary and restricts such a right to government officials according to the subject matter of the lawsuit [15]. This legal vacuum creates many practical problems for environmental organizations seeking to respond to environmental damage. However, in the case-law of Iran, the right of access to judicial authorities can be inferred based on some scattered regulations and their extensive presentation and interpretation.

\subsubsection{Constitutional Law}

Article 34 of the Constitution states: Litigation is the inalienable right of every person, and everyone can refer to the competent courts for litigation. All members of the nation have the right to access such courts, and no one can. The principle of this constitutional principle must be found in Article 8 of the Universal Declaration of Rights.

Man searched. Paying attention to terms such as "every person," "everyone," "all members of the nation," and "no one" in the constitution suggests that there is a legal basis for the presence of non-governmental organizations in the proceedings; At the same time, this has been identified in other principles of this law and under different titles. The question is whether the non-specification of the right of non-governmental organizations to sue can prevent the presence of these organizations?

Given the current facts and the nature of environmental crimes, depriving these organizations of access to judicial authority does not seem logical. In the international arena, these organizations play a role in various ways; One of the most obvious examples of this participation is their presence in the presence of some international judicial authorities, who are referred to as "friends of the court." This institution is inspired by the rights of the Anglo-Saxon countries and has gradually found its way into international law.

Does the fundamental question remain whether these organizations can be considered genuine in environmental litigation and be directly involved in litigation? Examining some general principles of the constitution, such as this law's fortieth and forty-fifth principles, can be helpful as a response[16].

The latter principle, while emphasizing "public interests" and "public interests," enumerates some environmental elements and refers to them as "Anfal and public wealth," which is at the disposal of the Islamic government to consume following public interests $[17,18]$.

Also, according to Article 50 of the Constitution: "In the Islamic Republic, the protection of the environment, in which today's generation and future generations should have a growing social life, is considered a public duty ...". Can file a lawsuit to protect the environment be considered a "public duty"? A positive answer to this question is reinforced by invoking the eighth and ninetieth principles of this law. According to the eighth principle, "In the Islamic Republic of Iran, calling for good, enjoining the good and forbidding 
the evil is a public and reciprocal duty of the people towards each other, the government towards the people and the people towards the government." "Its conditions, limits, and quality are determined by law ...". According to the ninetieth principle, "Anyone who has a complaint about the work of the parliament or the executive or the judiciary can submit his complaint in writing to the Islamic Consultative Assembly ..." The term "anyone" mentioned in this principle can apply to all persons. Include real and legal. Therefore, it seems that non-governmental organizations can not be deprived of the right of access to judicial authorities to protect the environment[19].

\subsubsection{By-Laws on the Establishment and Activities of Non-Governmental Organizations}

As mentioned, the right of NGOs to sue for environmental crimes under certain constitutional principles; In addition, among other governing regulations, we can mention the executive regulations for the establishment and activity of non-governmental organizations approved by the Cabinet on 20 June 2005, which directly addresses this issue.

This regulation allows non-governmental organizations to act following the subject of their activity, comply with this regulation and other related laws and regulations, and exercise the right to sue in judicial and quasi-judicial authorities. According to Article 16 of this regulation, "the organization [non-governmental organizations] have the right to file lawsuits against natural and legal persons in the courts in the field of their activities and to protect the public interest[71]."

This is the only article that allows non-governmental organizations to sue in the name of the public interest. Therefore, the right to sue is generally accepted for these organizations; These organizations can file lawsuits in line with their activities' subject matter and protect the public interest. The reference to "public interest" in this article is in line with Article 50 of the Constitution; Because environmental protection is considered a "public duty" in this principle. Accordingly, litigation by environmental NGOs to protect the environment is a "public duty" performed by these organizations during the proceedings.

Despite what has been said, the legal framework for such a right is a matter for reflection; Because, formally, by-laws are rules, not laws; Therefore, there is no guarantee of legal implementation, and it is based on the fact that according to Article One Hundred and Seventy, "judges of courts are obliged to refrain from enforcing government decrees and regulations that are contrary to Islamic laws and regulations or outside the powers of the executive branch." Anyone can request the annulment of such regulations from the Court of Administrative Justice "[19]. The provision of the right to sue for non-governmental organizations in the said regulation alone is not sufficient; To fulfill Article 50 of the Constitution, the legislature must prepare the ground for the active participation of these organizations in the proceedings.

In response to this legal vacuum, the judiciary in 2008, following the submission of some demands by non-governmental organizations on the one hand and the confrontation of judges with numerous lawsuits by non-governmental environmental networks, on the other hand, seeks to identify the position for this. According to Article 66 of the new draft Code of Criminal Procedure: "It is a matter of protecting citizens' rights. They can file charges for crimes committed in the above areas and protest at all stages of the proceedings to provide evidence of participation and against the rulings of the judicial authorities."

To strengthen the role of non-governmental organizations in the criminal process and to intend to support the victims of specific crimes, this article confirms their effective and useful presence in the criminal proceedings. It should be noted that the way the article is written can involve two conflicting interpretations; The first interpretation is that the article only grants the right to "plead guilty" to non-governmental organizations active in the areas in question and refuses to grant them the position of the litigant. The second interpretation, which is more compatible with the objectives of civil rights in general and 
environmental law in particular, is that according to the last part of the article, which refers to the organizations mentioned above, "in all stages of the proceedings Judiciary "grants the right to object, the legislature has granted positions to non-governmental organizations in lawsuits subject to the article. In other words, it does not make much sense for the legislature to grant these organizations the right to object or appeal the rulings on those disputes without granting them the right to sue[72].

In addition, granting the right to participate in all stages of litigation and the right to object to the opinions of judicial authorities is a significant consideration of the existence of "legal interest" for these organizations as the beneficiary of these lawsuits. Furthermore, this right is enshrined in Chapter 3 of the bill, entitled "Duties and Powers of the Prosecutor," which implies granting a quasi-judicial function to non-governmental organizations; This is an unparalleled innovation in Iranian law[20].

\section{Conclusions}

In extrajudicial trials, granting legal status to non-governmental organizations for "declaring a crime," filing a lawsuit, presenting evidence and proof of a crime, participating in all stages of criminal proceedings, and finally "challenging court rulings" are major developments. Which, on the one hand, eliminates one of the gaps in the Iranian legal system and, on the other hand, ensures the effective participation of these organizations in the implementation of environmental norms; In addition, the realization of the effective participation of such institutions in the criminal process will lead to the expansion of environmental protection authorities from governmental to non-governmental authorities.

In a general conclusion, the main obstacles facing these organizations in preventing and suppressing environmental crimes caused by the following factors; Some of these factors are related to these organizations and others are beyond their authority: A) Excessive diversity of non-governmental organizations in the field of environment and lack of coordination in determining the goals and executive mechanisms between them; B) weak relations of these organizations with the government and government institutions; $\mathrm{C}$ ) the dispersion of environmental duties and competencies between government organizations and institutions and the extensive ownership and domination of the government and government institutions over the environment; D) Lack of comprehensive and independent legislation regarding the establishment and activities of non-governmental organizations; E) Lack of effective legal mechanisms for the active participation of these organizations in the criminal process; F) The emptiness of the Ministry of Environment and the lack of accountability of the head of the Environmental Protection Organization before the Islamic Consultative Assembly.

However, what can be most effective in preventing and suppressing environmental crimes is creating a favorable environment for public participation in environmental protection in the form of non-governmental organizations; Achieving this partnership requires free access to environmental information, public participation in the decision-making process; decision-making, litigation, and environmental justice.

Supplementary Materials: “Not applicable."

Author Contributions: "Conceptualization, AS and EA; validation, NN, EA, and AS; formal analysis, EA.; investigation, EA.; resources, NN.; writing-original draft preparation, NN.; writing-review and editing, AS.; visualization, EA.; supervision, NN.; project administration, NN. All authors have read and agreed to the published version of the manuscript."

Funding: "This research received no external funding."

Data Availability Statement: “Not applicable." 
Conflicts of Interest: "The authors declare no conflict of interest."

\section{References}

[1] Bruch, C.; United Nations Environment Programme. Environmental Rule of Law: First Global Report; UNEP: Nairobi, Kenya, 2019; ISBN 978-92-807-3742-4.

[2] Park, S.; Kramarz, T. (Eds.) Global Environmental Governance and the Accountability Trap; Earth System Governance; The MIT Press: Cambridge, MA, USA, 2019; ISBN 978-0-262-03906-2.

[3] Hofmann, A. Left to Interest Groups? On the Prospects for Enforcing Environmental Law in the European Union. Environ. Polit. 2019, 28, 342-364.

[4] Pereira, R.M. Environmental Criminal Liability and Enforcement in European, and International Law; Queen Mary Studies in International Law; Brill Nijhoff: Leiden, The Netherlands; Boston, MA, USA, 2015; ISBN 978-90-04-19473-1.

[5] Faure, M.; Heine, G. (Eds.) Criminal Enforcement of Environmental Law in the European Union; Comparative Environmental Law \& Policy Series; Kluwer Law International: The Hague, The Netherlands; Frederick, MD, USA, 2005; ISBN 978-90-411-23374.

[6] Increasing the Effectiveness of International Environmental Law: Duties of States, Rights of Individuals; Le Club des Juristes: Paris, France, 2015.

[7] Shelton, D. Whiplash and Backlash - Reflections on a Human Rights Approach to Environmental Protection. Santa Clara J. Int. Law 2015, 13, 11.

[8] Wang, Y.; Li, Y.; Ma, Z.; Song, J. The Deterrence Effect of a Penalty for Environmental Violation. Sustainability 2019, 11, 4226.

[9] Lynch, M.J.; Barrett, K.L.; Stretesky, P.B.; Long, M.A. The Weak Probability of Punishment for Environmental Offenses and Deterrence of Environmental Offenders: A Discussion Based on USEPA Criminal Cases, 1983-2013. Deviant Behav. 2016, 37, 1095-1109.

[10] Simons, P. International Law's Invisible Hand and the Future of Corporate Accountability for Violations of Human Rights. J. Hum. Rights Environ. 2012, 3, 5-43.

[11] Maciková, L.; Smorada, M.; Dorčák, P.; Beug, B.; Markovič, P. Financial Aspects of Sustainability: An Evidence from Slovak Companies. Sustainability 2018, 10, 2274.

[12] Simpson, S.S.; Roria, M. Motivating Compliance: Economic and Material Motives for Compliance. In Explaining Compliance: Business Responses to Regulation; Edward Elgar Publishing: Cheltenham, UK, 2011.

[13] White, R. Reparative Justice, Environmental Crime and Penalties for the Powerful. Crime Law Soc. Chang. 2017, 67, 117-132.

[14] Mergen, A. Die Kriminologie: Eine Systematische Darstellung; Verlag Franz Vahlen Verlag: Munich, Germany, 1967.

[15] Brian, B. Sustainability and Intergenerational Justice. In Fairness and Futurity; Oxford University Press: New York, NY, USA, 1999; ISBN 0-19-829488-3.

[16] Lynch, M.J.; Stretesky, P.B.; Long, M.A. Environmental Crime Prosecutions in Ireland, 2004-2014. Int. J. Comp. Appl. Crim. Justice 2019, 43, 277-293.

[17] Müllerová, H. Právo na Životní Prostředí =: The Right to Environment; Vydání 1; Ústav Státu a Práva AV ČR, v.v.i: Prague, Czech Republic, 2015; ISBN 978-80-87439-21-0.

[18] Davis, T.; Hennes, E.P.; Raymond, L. Cultural Evolution of Normative Motivations for Sustainable Behaviour. Nat. Sustain. 2018, $1,218-224$.

[19] Suray Prasad Sharma Dhungel v. Godavari Marble Industries and Others WP 35/1992 (1995.10.31). Available online: https://www.elaw.org/content/nepal-suray-prasad-sharma-dhungel-v-godavari-marble-industries-and-others-wp-35199219951031 (accessed on 8 June 2021).

[20] Smith, L.D.-R.; Curling, R. NGOs Win Legal Battle over Access to Environmental Justice/Lexology. Available online: https://www.lexology.com/library/detail.aspx?g=0f9f4559-7a50-4a0b-a5ba-b3b285fab113 (accessed on 27 March 2021).

[21] Bergman, P.; Berman-Barrett, S.J. The Criminal Law Handbook: Know Your Rights, Survive the System; Nolo: Berkeley, CA, USA, 2020; ISBN 978-1-4133-2719-9.

[22] Horder, J. Ashworth's Principles of Criminal Law, 9th ed.; Oxford University Press: Oxford, UK, 2019; ISBN 978-0-19-877766-3.

[23] Triffterer, O. Österreichisches Strafrecht: Allgemeiner Teil; Springer: Wien, Austria, 1985; ISBN 978-3-211-81856-5.

[24] Aragão, A.; Carvalho, A. Taking Access to Justice Seriously: Diffuse Interests and Actio Popularis. Why Not? Environmental Law Network International Review: Bingen, Germany, 2017; pp. 42-48.

[25] Vera, E. Inventory of EU Member States' Measures on Access to Justice in Environmental Matters: The Aarhus Convention: How Are Its Access to Justice Provisions Being Implemented? European Commission: Brussels, Belgium, 2008.

[26] Gunningham, N. Enforcing Environmental Regulation. J. Environ. Law 2011, 23, 169-201.

[27] United Nations Environment Programme; Association of South East Asian Nations Environmental Cooperation Centre. Enforcement of Environmental Law: Good Practices from Africa, Central Asia, ASEAN Countries and China. In Proceedings of the Africa-Asia Expert Meeting on Enforcement of Environmental Law, Nairobi, Kenya, 13-14 August 2014.

[28] Wilson, C.D.H.; Williams, I.D.; Kemp, S. An Evaluation of the Impact and Effectiveness of Environmental Legislation in Small and Medium-Sized Enterprises: Experiences from the UK: Evaluation of Impact + Effectiveness of Environ Legislation in SMEs. Bus. Strategy Environ. 2012, 21, 141-156. 
[29] Young, O.R. Effectiveness of International Environmental Regimes: Existing Knowledge, Cutting-Edge Themes, and Research Strategies. Proc. Natl. Acad. Sci. USA 2011, 108, 19853-19860.

[30] Morgera, E. Corporate Accountability in International Environmental Law; Oxford University Press: Oxford, UK, 2009; ISBN 978-0-19-955801-8.

[31] Navarra, C.; European Parliament; European Parliamentary Research Service; European Value Added Unit. Corporate Due Diligence and Corporate Accountability: European Added Value Assessment. Available online: https://www.europarl.europa.eu/RegData/etudes/STUD/2020/654191/EPRS_STU(2020)654191_EN.pdf (accessed on 23 March 2021).

[32] Baars, G. The Corporation, Law and Capitalism: A Radical Perspective on the Role of Law in the Global Political Economy; Historical Materialism Book Series; Brill Nijhoff: Leiden, The Netherlands; Boston, MA, USA, 2019; ISBN 978-90-04-39286-1.

[33] European Commission; Directorate General for Justice and Consumers; British Institute of International and Comparative Law; Civic Consulting; LSE. Study on Due Diligence Requirements through the Supply Chain: Final Report; Publications Office LU: Brussels, Belgium, 2020.

[34] Latapí Agudelo, M.A.; Jóhannsdóttir, L.; Davídsdóttir, B. A Literature Review of the History and Evolution of Corporate Social Responsibility. Int. J. Corp. Soc. Responsib. 2019, 4, 1.

[35] Rosati, F.; Faria, L.G.D. Addressing the SDGs in Sustainability Reports: The Relationship with Institutional Factors. J. Clean. Prod. 2019, 215, 1312-1326.

[36] Sroka, W.; Szántó, R. Corporate Social Responsibility and Business Ethics in Controversial Sectors: Analysis of Research Results. J. Entrep. Manag. Innov. 2018, 14, 111-126.

[37] Anser, MK; Zhang, Z.; Kanwal, L. Moderating Effect of Innovation on Corporate Social Responsibility and Firm Performance in Realm of Sustainable Development. Corp. Soc. Responsib. Environ. Manag. 2018, 25, 799-806.

[38] Jung, S.; Ha-Brookshire, J. Perfect or Imperfect Duties? Developing a Moral Responsibility Framework for Corporate Sustainability from the Consumer Perspective: Moral Responsibility Framework for Corporate Sustainability. Corp. Soc. Responsib. Environ. Manag. 2017, 24, 326-340.

[39] Dixon, R.; Mousa, G.A.; Woodhead, A. The Role of Environmental Initiatives in Encouraging Companies to Engage in Environmental Reporting. Eur. Manag. J. 2005, 23, 702-716.

[40] Damohorský, M. Právo Životního Prostředí; C.H. Beck: Prague, Czech Republic, 2010; ISBN 978-80-7400-338-7.

[41] Jančářová, I.; Masarykova Univerzita; Katedra Práva Životního Prostředí a Pozemkového Práva. Odpovědnost v Právu Životního Prostředí-Současný Stav a Perspektivy; Masarykova Univerzita: Brno, Czech Republic, 2013; ISBN 978-80-210-6594-9.

[42] Langbroek, P.; Van den Bos, K.; Simon Thomas, M.; Milo, M.; Van Rossum, W. Editorial Methodology of Legal Research: Challenges and Opportunities. Utrecht Law Rev. 2017, 13, 1.

[43] Tyler, T.R. Methodology in Legal Research. Utrecht Law Rev. 2017, 13, 130.

[44] Melzer, F. Metodologie Nalézání Práva: Úvod do Právní Argumentace; C.H. Beck: Prague, Czech Republic, 2011; ISBN 978-807400-382-0.

[45] Bydlinski, F. Juristische Methodenlehre Und Rechtsbegriff; 2., erg. Aufl.; Springer: Wien, Austria; New York, NY, USA, 1991; ISBN 978-3-211-82270-8.

[46] Kramer, E.A.; Stämpfli, A.G. Manz'sche Verlags- und Universitätsbuchhandlung; C.H. Beck: Munich, Germany, 2019; ISBN 9783-7272-3462-0.

[47] Eser, A.; Burkhardt, B. Strafrecht; Juristischer Studienkurs; 4., Wesentlich Überarbeitete Aufl.; C.H. Beck: München, Germany, 1992; ISBN 978-3-406-09813-0.

[48] Kühn, Z. Aplikace Práva ve Složitých Př́ípadech: K Úloze Právních Principů v Judikatuře; Karolinum: Prague, Czech Republic, 2002; ISBN 978-80-246-0483-1.

[49] Kienapfel, D; Höpfel, F. Grundriss Des Strafrechts: Allgemeiner Teil; Manzsche Kurzlehrbuch-Reihe; 11., Überarbeitete und Erw. Aufl.; Manz: Wien, Austria, 2005; ISBN 978-3-214-12176-1.

[50] United Nations. Human Rights Council A/HRC/37/59 Report of the Special Rapporteur on the Issue of Human Rights Obligations Relating to the Enjoyment of a Safe, Clean, Healthy and Sustainable Environment. 2018. Available online: https://undocs.org/A/HRC/37/59 (accessed on 25 March 2021).

[51] United Nations; Office of the High Commissioner for Human Rights. Guiding Principles on Business and Human Rights: Implementing the United Nations "Protect, Respect and Remedy" Framework. 2011. Available online: https://www.un-ilibrary.org/content/books/9789210541206 (accessed on 25 March 2021).

[52] Cardwell, P.J.; French, D.; Hall, M. Tackling Environmental Crime in the European Union: The Case of the Missing Victim? Environ. Law Manag. 2011, 23, 113-121.

[53] Barnard, C.; Peers, S. (Eds.) European Union Law, 3rd ed.; Oxford University Press: Oxford, UK, 2020; ISBN 978-0-19-885575-0.

[54] Lalík, T. Understanding the Binding Effect of the Case-Law of the ECtHR in Domestic Legal Order; Social Science Research Network: Rochester, NY, USA, 2011.

[55] European Court of Human Rights Guide on Article 2 of the European Convention on Human Rights - Right to Life. Available online: https://www.echr.coe.int/Documents/Guide_Art_2_ENG.pdf (accessed on 8 June 2021).

[56] European Court of Human Rights Chamber Judgment KU. v. Finland. Available online: https://hudoc.echr.coe.int/fre\#\{\%22itemid\%22:[\%22003-2564792-2788755\%22]\} (accessed on 8 June 2021). 
[57] European Court of Human Rights Judgment Osman v. the United Kingdom. Available online: https://hudoc.echr.coe.int/fre\#\{\%22itemid\%22:[\%22002-6781\%22]\} (accessed on 8 June 2021).

[58] European Court of Human Rights Judgment Vasyukov v. Russia. Available online: https://hudoc.echr.coe.int/fre\#\{\%22itemid\%22:[\%22001-104295\%22]\} (accessed on 8 June 2021).

[59] Hlaváčová, L. Účast Veřejnosti Na Rozhodovacích Procesech v Rámci Ochrany Životního Prostředí-Obecný Rozbor Institutu. AUC Iurid. 2021, 67, 85-102.

[60] Jelínek, J. Nad koncepcí trestní odpovědnosti právnických osob v českém trestním právu. Kriminalistika 2016, 49, 3-18.

[61] Ladychenko, V.; Yara, O.; Uliutina, O.; Golovko, L. Environmental Liability in Ukraine and the EU. Eur. J. Sustain. Dev. 2019, 8, 261.

[62] Dubber, MD; Hörnle, T. Criminal Law: A Comparative Approach, 1st ed.; Oxford University Press: Oxford, UK; New York, NY, USA, 2014; ISBN 978-0-19-958960-9.

[63] Shute, S.; Simester, A.P. (Eds.) Criminal Law Theory: Doctrines of the General Part; Oxford University Press: Oxford, UK; New York, NY, USA, 2002; ISBN 978-0-19-924349-5.

[64] Dyson, M. Comparing Tort and Crime: Learning from Across and within Legal Systems; Cambridge University Press: Cambridge, UK, 2015; ISBN 978-1-139-94628-5.

[65] Loveless, J. Complete Criminal Law: Text, Cases, and Materials; Oxford University Press: New York, NY, USA, 2018; ISBN 9780-19-880327-0.

[66] Czech Constitutional Court Judgment 2012/18; national adopted policy, 2019.

[67] Czech Constitutional Court Judgment 3436/14; national adopted policy, 2016.

[68] Czech Constitutional Court Judgment 3196/12; nationally adopted policy, 2014.

[69] Aristotle. The Nicomachean Ethics; Brown, L., Ed.; Ross, W.D., Translator; Oxford University Press: Oxford, UK; New York, NY, USA, 2009; ISBN 978-0-19-921361-0.

[70] Farrow, K.; Grolleau, G.; Ibanez, L. Social Norms and Pro-Environmental Behavior: A Review of the Evidence. Ecol. Econ. 2017, $140,1-13$.

[71] Rob, W. NGO Engagement in Environmental Law Enforcement: Critical Reflections. In Transnational Environmental Crime; Routledge: London, UK, 2012; Available online: https://search.informit.org/doi/10.3316/informit.69965767997916 (accessed on 8 June 2021).

[72] Epstein, Y.; Kantinkoski, S. Non-Governmental Enforcement of EU Environmental Law: A Stakeholder Action for Wolf Protection in Finland. Front. Ecol. Evol. 2020, 8, 101. Author 1, A.; Author 2, B. Title of the chapter. In Book Title, 2nd ed.; Editor 1, A., Editor 2, B., Eds.; Publisher: Publisher Location, Country, 2020; Volume 5, pp. 154-196. 